[Radiocarbon, Vol. 13, No. 2, 1971, P. 412-419]

\title{
REHOVOT RADIOCARBON MEASUREMENTS I
}

\author{
I. CARMI, Y. NOTER*, and R. SCHLESINGER
}

Department of Isotope Research, Weizmann Institute of Science, Rehovot, Israel

The Rehovot Radiocarbon Laboratory was established in 1968, as an extension of a low-level tritium laboratory, which has been in operation many years. Intended to be a supporting facility in geohydrological studies, the laboratory now offers general services in carbon dating.

For measurements, we use proportional gas counting of ethane, at 2100 torr. The sample counter is a modified RCL counter, of $1.1 \mathrm{~L}$ volume; it is operated at 5600 volts. The counter is surrounded, respectively, by a Johnston GRC-13 anticoincidence guard counter, $2 \mathrm{~cm}$ old lead, $10 \mathrm{~cm}$ boron loaded paraffin, and $25 \mathrm{~cm}$ pre-2nd-world-war steel. Samples are counted in four channels, in anticoincidence with the guard counter. The four channels count disintegrations between the following energies: channel 1: 1 to $18 \mathrm{keV}$, channel 2: 18 to $59 \mathrm{keV}$, channel 3: 59 to $155 \mathrm{keV}$, and channel 4: above $155 \mathrm{keV}$. $\mathrm{C}^{14}$ is counted in the two middle channels; channel 1 is rejected against possible tritium contamination, and channel 4 is used to detect Radon contamination. The working point is determined by coincidence counting of charged cosmic particles: the ratio of count rates in the two sample channels is adjusted to 1.

The acquisition and processing of counting data is done automatically by an on-line computer (Carmi and Ashkenazi, 1970).

Background samples are prepared from alabaster or from anthracite. The average of 21 background measurements was $3.77 \pm .08 \mathrm{cpm}$. The calibration standard is the NBS oxalic acid standard. The average of 9 standard measurements was $24.40 \pm 0.11 \mathrm{cpm}$ (after multiplication by $.95)$. According to convention, the half life used is 5568 years.

The chemical procedure is, first, to prepare the sample so that it can be converted to $\mathrm{CO}_{2}$. Next, solid or dissolved carbonates are treated by acid, and organic matter is combusted in dry oxygen stream. The $\mathrm{CO}_{2}$ is purified, and converted to ethane in the following steps: carbidization of lithium (Barker, 1953), hydrolysis to acetylene, and hydrogenation to ethane over palladium catalyst (Bainbridge et al., 1961).

The facility was established with the aid of a grant by the Ford Foundation. $\mathrm{C}^{13}$ analyses are performed on an M-86 mass-spectrometer, donated by the Volkswagen Stiftung.

\section{SAMPLE DESCRIPTIONS}

\section{ATMOSPHERIC SAMPLES}

Atmospheric $\mathrm{CO}_{2}$ is collected weekly at Rehovot, (1460-1315) local grid. Collection is by exposure of concentrated $\mathrm{NaOH}$ solution to the

* Left in 1969. 
atmosphere. The results of 23 of the samples, collected between 1968 and 1970, are given below. Before 1968, several Rehovot samples were measured by R. Nydal of Trondheim. Comment: (I.C.) decrease in the concentrations, beginning in spring 1969 , is definitely noticeable.

\begin{tabular}{|c|c|c|c|c|}
\hline \multirow{2}{*}{$\begin{array}{c}\text { Sample no. } \\
\text { RT-122 }\end{array}$} & \multicolumn{3}{|c|}{ Exposure dates } & \multirow{2}{*}{$\begin{array}{c}\delta \mathrm{C}^{14 \%} \% \\
62.2 \pm 1.7\end{array}$} \\
\hline & March & 18, 1968-March & 22,1968 & \\
\hline RT-123 & March & 25, 1968-March & 31,1968 & $58.1 \pm 1.2$ \\
\hline RT-124 & April & 15, 1968-April & 21,1968 & $57.1 \pm 1.2$ \\
\hline RT-125 & April & 29, 1968-May & 5, 1968 & $57.1 \pm 0.9$ \\
\hline RT-126 & July & 7, 1968-July & 12,1968 & $55.7 \pm 1.2$ \\
\hline RT. 127 & July & $22,1968-J u l y$ & 28,1968 & $61.1 \pm 1.1$ \\
\hline RT-157 & Sept. & 16, 1968-Sept. & 20,1968 & $60.7 \pm 0.3$ \\
\hline RT 158 & Sept. & 30, 1968-Oct. & 4, 1968 & $67.1 \pm 1.3$ \\
\hline RT-159 & Oct. & $15,1968-$ Oct. & 18,1968 & $59.6 \pm 1.4$ \\
\hline RT-160 & Oct. & $28,1968-$ Nov. & 1,1968 & $58.8 \pm 1.6$ \\
\hline RT-161 & Nov. & 11, 1968-Nov. & 17,1968 & $60.4 \pm 0.9$ \\
\hline RT-162 & Dec. & 9, 1968-Dec. & 13,1968 & $57.9 \pm 1.7$ \\
\hline RT-163 & Jan. & 6, 1969-Jan. & 10,1969 & $58.7 \pm 1.7$ \\
\hline RT-164 & Feb. & 17, 1969-Feb. & 21,1969 & $59.1 \pm 1.4$ \\
\hline RT-166 & April & 14, 1969-April & 20,1969 & $60.4 \pm 1.5$ \\
\hline RT-199 & June & $16,1969-J u n e$ & 22, 1969 & $61.2 \pm 1.2$ \\
\hline RT-200 & July & 21, 1969-July & 25,1969 & $59.3 \pm 1.5$ \\
\hline RT-201 & Aug. & 18, 1969-Aug. & 22,1969 & $57.2 \pm 1.5$ \\
\hline R'T-202 & Sept. & 29, 1969-Oct. & 1, 1969 & $57.8 \pm 1.7$ \\
\hline RT-203 & Oct. & 24,1969 -Oct. & 24,1969 & $57.6 \pm 1.5$ \\
\hline RT-204 & Nov. & 11, 1969-Nov. & 21,1969 & $53.4 \pm 1.5$ \\
\hline RT-205 & Dec. & 15, 1969-Dec. & 19,1969 & $55.4 \pm 1.4$ \\
\hline RT-206 & Jan. & 19, 1970-Jan. & 23,1970 & $45.5 \pm 1.3$ \\
\hline
\end{tabular}

\section{WATER SAMPLES}

Water samples are collected for a preliminary survey of the $\mathbf{C}^{14}$ concentration distribution in Israel waters, and for possible age estimations. Samples are brought in fiberglass containers from field to laboratory, where the carbonates are precipitated as $\mathrm{BaCO}_{3}$. The coordinates are given in the local grid.

Ages are calculated after Ingerson and Pearson (1964), with $\delta \mathrm{C}^{13}{ }_{1 \mathrm{~s}}$ $=0$ in the mother rock. They should, therefore, be regarded with reservations. Comment (I.C.): in the 2 cases that the calculation gave more than $100 \%$ concentration, results are supported by tritium data, which shows that the samples contain water components, or are completely, of post-thermonuclear origin. 


\begin{tabular}{|c|c|c|c|c|}
\hline Sample & Name & Type & $\begin{array}{c}\text { Coordinates } \\
\text { (local grid) }\end{array}$ & $\begin{array}{l}\text { Depth } \\
\text { (m) }\end{array}$ \\
\hline \multicolumn{5}{|c|}{ a. Northern Arava ( $\mathrm{S}$ of the Dead Sea) } \\
\hline RT-101 & Tamar 7 & well & $0458-1805$ & 345 \\
\hline $\mathrm{RT}-108$ & $\operatorname{Zin} 6$ & well & 0440-1833 & 50 \\
\hline RT-117 & Tamar 3 & well & 0433-1787 & 76 \\
\hline RT-131 & Tamar 3 & well & $0433-1787$ & 76 \\
\hline $\mathrm{RT}-156$ & Neot Hakikar & well & 0388-1863 & 73 \\
\hline RT-193 & Tamar 3 & well & $0433-1787$ & 400 \\
\hline \multicolumn{5}{|c|}{ b. Southern Arava ( $\mathrm{N}$ of Eilat) } \\
\hline RT-107 & Yotvata 2 & well & $9225-1544$ & 50 \\
\hline RT-112 & Timna 5 & well & $9116-1517$ & 116 \\
\hline \multicolumn{5}{|c|}{ c. Negev } \\
\hline RT-115 & Dimona 1 & well & 0496-1624 & 89 \\
\hline RT-129 & Dimona 1 & well & 0496-1624 & 89 \\
\hline RT-136 & Beer Sheva 3 & well & 0716-1289 & 267 \\
\hline $\mathrm{RT}-137$ & Omer & well & $0750-1348$ & 539 \\
\hline RT-138 & Hatzerim & well & $0720-1270$ & 238 \\
\hline RT-196 & Makhtesh 3 & well & $0400-1710$ & 763 \\
\hline \multicolumn{5}{|c|}{ d. Sinai } \\
\hline $\mathrm{RT}-195$ & Ein Fourtaga & spring & $8290-7070$ & \\
\hline \multicolumn{5}{|c|}{ e. Dead Sea Coast (N) } \\
\hline $\mathrm{RT}-157$ & Ein Feshcha & spring & $1250-1940$ & \\
\hline RT-155 & Ein Feshcha & spring & $1250-1940$ & \\
\hline \multicolumn{5}{|c|}{ f. Central Lowlands } \\
\hline RT-152 & Lod 23 & well & $1530-1420$ & 276 \\
\hline RT-153 & Lod 26 & well & $1540-1430$ & 76 \\
\hline $\mathrm{RT}-194$ & Rosh Ha'ayin & well & $1660-1425$ & 119 \\
\hline \multicolumn{5}{|c|}{ g. Tel-Aviv } \\
\hline $\begin{array}{l}\text { RI-167 } \\
\text { RT-168 }\end{array}$ & $\begin{array}{l}\text { Reading } \\
\text { Gordon }\end{array}$ & $\begin{array}{l}\text { well } \\
\text { well }\end{array}$ & $\begin{array}{l}1680-1290 \\
1640-1280\end{array}$ & $\begin{array}{l}32 \\
60\end{array}$ \\
\hline \multicolumn{5}{|c|}{ h. Lake Tiberias area } \\
\hline RT-103 & Ein Noon & spring & 2497-1982 & \\
\hline $\mathrm{RT}-106$ & Hamat Gader & spring & $2327-2129$ & \\
\hline RT-109 & Tiberias Hot & & & \\
\hline & Springs & spring & 2414-2017 & \\
\hline RT-154 & Kineret 8 & well & 2013-2517 & 715 \\
\hline
\end{tabular}




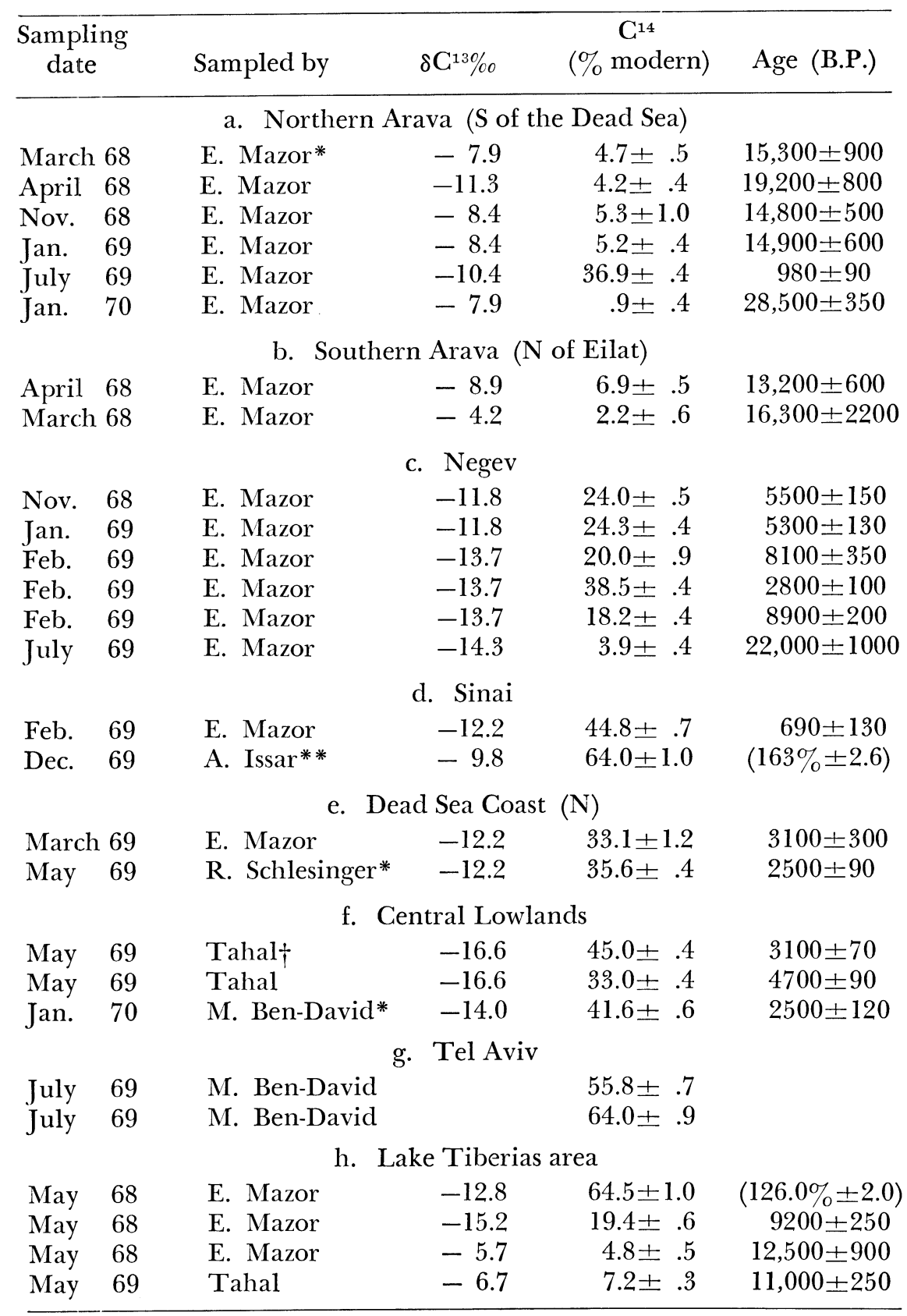

* Weizmann Institute of Science, Rehovot.

** Geological Survey of Israel, Jerusalem.

$\uparrow$ Water Planning for Israel Ltd, Tel Aviv. 


\section{GEOLOGIC SAMPLES} in Fig. 1.

The coordinates are given in the local grid, and locations are shown

\section{A. Secondary calcites}

In secondary calcites, it is assumed that the carbon in the carbonate has been affected by interactions between water and country rock. It is possible, therefore to calculate the age of the sample, correcting for the $\delta \mathrm{C}^{13}$ value by the method of Ingerson and Pearson (1964), using the value of the country rock as $\delta \mathrm{C}^{13}{ }_{1 \mathrm{~s}}$.

\section{Qsalon series}

Secondary calcites (Nari) on a dolomite in a Cenomenian stratum near Qsalon (1312-1532), in the Judean Mts., Region $\mathrm{k}$ in Fig. 1. Coll. and subm. Feb., 1970 by M. Magaritz, Weizmann Inst. of Sci. For age calculation, $\delta \mathrm{C}^{13}{ }_{1 \mathrm{~s}}=+1 \%$ in the dolomite. Comment: to avoid attacking the dolomite, a $4 \% \mathrm{HCl}$ solution was used for liberating $\mathrm{CO}_{2}$ from the samples.

\begin{tabular}{|c|c|c|c|c|}
\hline Sample & $\begin{array}{l}\text { Height } \\
\text { above } \\
\text { dolomite } \\
\text { (cm) }\end{array}$ & $\begin{array}{c}\mathrm{C}^{14} \\
(\% \text { modern })\end{array}$ & $\delta \mathrm{C}^{13}(\% 0)$ & Age B.P. \\
\hline RT-211. Qsalon 2 & 0 & $7.5 \pm .5$ & -10.0 & $13,700 \pm 850$ \\
\hline RT-213. Qsalon 3 & 40 & $9.6 \pm .5$ & -9.6 & $12,480 \pm 350$ \\
\hline RT-197. Qsalon 1 & 80 & $10.7 \pm .4$ & -10.4 & $11,200 \pm 500$ \\
\hline RT-217. Qsalon 4 & 120 & $17.0 \pm .6$ & -10.4 & $6600 \pm 600$ \\
\hline
\end{tabular}

\section{Hermon series}

Coarse crystalline calcite in a karst in Jurassic rock on Mt. Hermon. Coll. and subm. April, 1970 by M. Magaritz.

\section{RT-215. Hermon 1}

From limestone (2980-2210). For age determination, $\delta \mathrm{C}^{13}{ }_{1 \mathrm{~s}}=-.5 \%$ in the country-rock calcite.

\section{RT-216. Hermon 2}

From dolomite adjacent to a magmatic dike (2960-2203). For age determination, $\delta \mathrm{C}^{13}{ }_{1 \mathrm{~s}}=+1.0 \%$ in the country-rock dolomite.

\section{Sha'ar Hagai series}

Secondary calcite in a Cenomenian stratum near Sha'ar Hagai, on hwy. to Jerusalem (7925-0155), Region k on Fig. 1. Coll. and subm. March, 1970 by M. Magaritz. For age determination, $\delta \mathrm{C}^{13}{ }_{1 \mathrm{~s}}=-1.0 \%$ in the country rock. 


\section{RT-195. Sha'ar Hagai 1}

\section{RT-192. Sha'ar Hagai 2}

$10 \mathrm{~cm}$ from RT-195.

$$
\begin{array}{r}
>\mathbf{4 0 , 0 0 0} \\
\mathbf{C}^{14}=\mathbf{1 . 1} \% \pm \mathbf{0 . 4} \\
\delta C^{13}=-12.2 \% 0 \\
\mathbf{2 9 , 0 0 0} \pm \mathbf{1 0 0 0} \\
\mathrm{C}^{14}=\mathbf{1 . 1} \% \pm \mathbf{0 . 4} \\
\delta C^{13}=-11.4 \% 0
\end{array}
$$

\section{B. Precipitates and shells}

These are reported as "per cent of modern" and $\delta \mathrm{C}^{13}$ in per mil. Ages are calculated only where there is an accepted method for the calculation.

\section{RT-182. Qabri Aqueduct}

$$
\mathbf{C}^{14}=\mathbf{7 1 . 4 \%} \% \mathbf{0 . 9}
$$

Precipitate in an aqueduct near Qabri, in W Galilee (2660-1600), in use until late 1940's. Coll. and subm. 1969 by A. Issar.

\section{RT-184. Feiran}

$$
\mathrm{C}^{14}=\mathbf{4 . 3 \%} \pm \mathbf{0 . 4}
$$

Lacustrine precipitate from upper-mid-Pleistocene in Sinai (70250155), coll. and subm. 1969 by A. Issar.

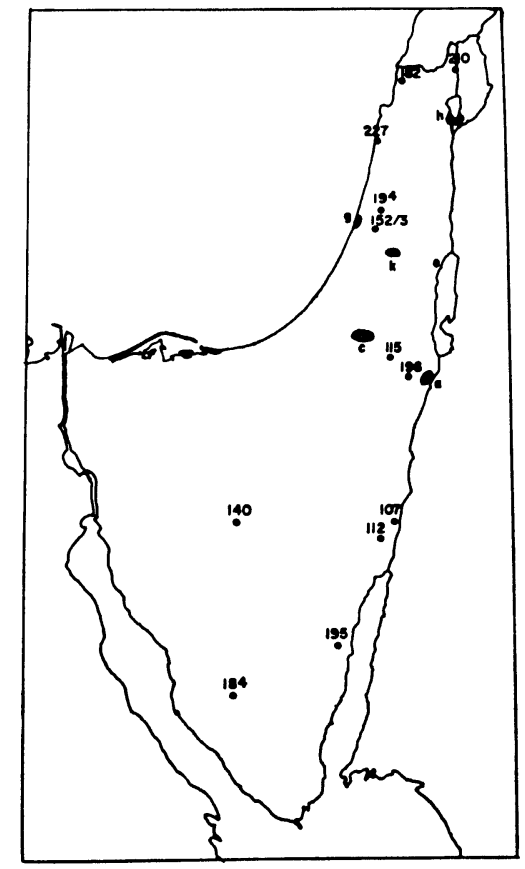

Fig. 1 


\section{RT-187. Ein Moreh}

$$
\begin{array}{r}
\mathbf{C}^{14}=\mathbf{2 . 3 \%} \pm \mathbf{0 . 4} \\
\delta C^{13}=-3.3 \% 0
\end{array}
$$

Travertine on limestone in Negev (0275-1270), coll. and subm. 1969 by A. Issar.

\section{RT-210. Hula shells}

$$
\begin{array}{r}
4600 \pm 100 \\
\mathrm{C}^{14}=\mathbf{6 1 . 0 \%} \pm \mathbf{0 . 8} \\
\delta C^{13}=-14.3 \%
\end{array}
$$

Shells (Unio sp.) from terrace of ancient Lake Hula, near Bnot Ya'aqov bridge in upper Galilee (2686-2083). Coll. and subm. March, 1970 by A. Horowitz, Geol. Survey of Israel, Jerusalem. Comment (A.H.): terrace was formed during last intrusion of Lake Hula into Bnot Ya'aqov region.

\section{Dead Sea driftwood}

\section{Organic matter}

Driftwood from localities higher than surface of Dead Sea $(-398.5 \mathrm{~m})$. Subm. April, 1970 by Zipora Klein, Jerusalem. Comment (I.C.): it is assumed that samples were deposited when sea was at present sample level. Assuming wood was then fresh, it can date change of level of Dead Sea (based on information by Z. Klein).

\section{RT-220. Dead Sea driftwood ZK5}

$200 \pm 100$

$$
\text { A.D. } 1750
$$

$$
\begin{array}{r}
\mathbf{C}^{14}=\mathbf{9 7 . 9 \%} \pm \mathbf{1 . 1} \\
\delta C^{13}=-23.5 \% \text { o }
\end{array}
$$

Driftwood from Nahal More (1858-0750), coll. April 1970 by Z. K. from alt $-376.5 \mathrm{~m}$.

\section{RT-221. Dead Sea driftwood ZK1}

$$
100 \pm 100
$$

$$
\text { A.D. } 1850
$$

$$
\mathbf{C}^{14}=\underset{8}{\mathbf{1 0 0 . 0} \%} \pm \mathbf{1 . 0}
$$

Driftwood from Mezad Qidron (1920-1211, local coordinates). Loc. is 8th century B.c. Israeli fort; sample was deposited by later flooding. Coll. 1968 by Z. Klein from $-385.7 \mathrm{~m}$.

\section{RT-226. Dead Sea driftwood ZK3}

$$
\left(\text { corr. } \mathrm{C}^{14}=100 \% \pm 1.0\right)
$$

$$
\begin{array}{r}
\mathrm{C}^{14}=\mathbf{9 8 . 9} \% \pm \mathbf{3 . 0} \\
\delta C^{13}=-30.8 \% \circ
\end{array}
$$

Driftwood from delta of Nahal Haver (1866-0912) coll. 1967 by Z. Klein from alt $-394 \mathrm{~m}$. Comment (I.C.): sample resembles eroded beach stone. Large error is due to small amount of sample.

General Comment: samples were treated with $\mathrm{HCl}$ to remove inorganic deposits.

$$
\text { IV. ARCHAEOLOGIC SAMPLES }
$$

\section{RT-227. Khabara 14}

$$
\begin{array}{r}
\mathbf{1 8 , 5 0 0} \pm \mathbf{3 0 0} \\
\mathrm{C}^{14}=\mathbf{9 . 5 \%} \pm \mathbf{0 . 2} \\
\delta C^{13}=-29.0 \%
\end{array}
$$

Ash from prehistoric cave in Carmel Mts. (2183-1444, local coordi- 
nates) from Layer 26 in stratigraphy which corresponds to Levantine Orignacian A. Coll. and subm. June 1970 by O. Bar-Yossef, Hebrew Univ., Jerusalem. Comments (I.C.): age determined on combusted residue of $\mathrm{HCl}$ and $\mathrm{NaOH}$ treated sample. (O.B-Y): archaeologic determination of ages is between 25,000 and 35,000 yr. B.P. Sample coll. from exposed ditch in excavation.

\section{REFERENCES}

Bainbridge, A. E., Sandoval, P., and Suess, H. E., 1961, Natural tritium measurements by ethane synthesis: Science, v. 134, p. 552.

Barker, H., 1953, Radiocarbon dating: large-scale preparation of acetylene from organic material: Nature, v. 172, p. 631.

Carmi, I. and Y. Ashkenazi, 1970, A computer on-line in low-level counting laboratory: Nuclear Instruments and Methods, in press.

Ingerson, E. and Pearson, F. J., 1964, Estimation of age and rate of motion of ground water. Recent researches in the field of hydrosphere, atmosphere and nuclear geochemistry: Maruzen Co. Ltd. 